Orthopedic Surgical Clinic, Yamaguchi Medical College

\title{
lnvestigation of Crippled Schoolchildren in Ube City
}

\section{by Tetsuo ITo, Seizo Ueki and Kazumasa Sanuki}

On investigation of 19131 schoolchildren in Ube city. It was revealed that the crippled children were eighty-three, 0.43 per cent.; nineteen of them, cerebral paralysis; fifteen, poliomyelitis; seven, congenital dislocation of hip joint.

\section{災害と外傷性骨网腫について

$\begin{array}{ccccc}\text { 八幡製鉄所病院整形外科 } \quad \text { 小 } & \text { 松 } & \text { 朝 } & \text { 幐 } \\ & \text { 長 } & \text { 良 } & \text { 執 } & \text { 中 }\end{array}$

緒

言

我国に特ける外傷性肉腫につんては 昭和 17 年後 藤外科教室から深松氏が 27 例につんて，昭和 25 年 12 月江名古屋齊藤外科教室の山田氏が淡害と悪性腫湯発生に就てと題して，その中に 103 例 の肉腫について詳細沉報告されている。其他九大整形外科教室の生田氏のスポーツ外傷による2例 の報告等がある。骨肉腫につんては前述の深松氏が同教室の大正 8 年より昭和 15 年にんたる 21 年

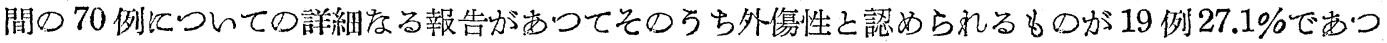
て，国内，外国諸教室の報告例の肉腫総数の約 $8.6 \%$ は外傷性肉腫であると報告されている。

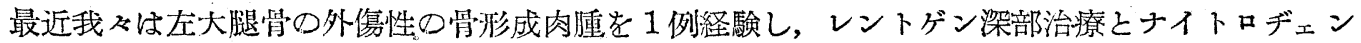
・マスタードーN一オキサイド（ナイトロミン）療法を併用しその影響や組織学的変化をしらべ娄 したのと，たまたま公傷として取报ふべきか否かの問題に当面したのと，且つ䁏椎に畸型を認めた ので，幸い当会には其の道の権威者も站られますし，且つそうした方面で関係亦る方及も多いと思 われますので報告致して皆㥞の御教示と御批判をいただきたいと思います。

症


には特剧のこはない。四肢についてば全く異常はな く患部に打撲等を受けたことはない。

昭和 26 年 11 月 1 日作業中頑丈な木箱の角で左大腿 下端部を強打した。すぐ，与らんと声を出して，自分 の席にもどり，しばらく括さへていた。幾分か治つて から, 急救箱を使つて, 沃度 チンキ党患部に塗布し た。疼痛があつたが师宅する面には忘れられる程度に なつた。現認証は畫いてもらわなかつたが前に打つた

\section{例}

发迲や周囲に招つた人々は確認していた。其夜は手で マッサージをした。权つきがわるい程度で不眠には ならなかつた。每 2 日は午前中は多忙のためか，意 識しなかつたが，午後痛むのと関節炎にならないか 気にか子り，同㭙に 3 日，4 日に予定されていたハイ キングのことが気になつて構内治療所へ行つて尋ねた 所が関節《腫脹してもいないし液もなくて何ともな い，単なる打撲程度であるから，むしろ歩いた方が早 く吸収されるかるしれないと云われ，患部にカンポリ 
ジンとビタミン剤の注射を受け，湿布をしてるらう た。安心して, 跛行しながら帰つた。3 日朝異常ない 様に感じたので，山口県へ栗拾いに行き，4 日忙平尾 台ヘハイキングに行つた。階段の昇降等には困難し跛 行しながらとにかく目的䍒果した。其後もずつと階段 杽降に困難し正坐が不能で夜間の方が疼痛があつて, 静かに下肢在下垂して㧊くより，水平に伸したりるん 脑りしている方がよい様であつた。漝和27年 2 月 1 日 月始め業摖多忙のため休業してはならないと思つて起 休しようどしたが，疼痛のため立上れないので初めて 診療を受けた。30万ペニシリンとビタミンCの注射を

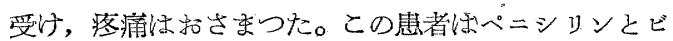
タミンCの注射で，時及疼みがとれた。レントゲン線 検查の結果, 肺に注買常安認めないが，腰椎に相当の 渏型のむる事と, 左大腿骨の内側下端に長さ 4 横指, 巾 3 横指, 厚さ最大約 0.8 粗位の骨膜性の骨性棁腫

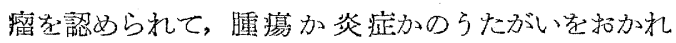
た。3日の夜間䛜目部に疼痛があつて医師より虫垂炎 の診断を受けた。2,3日して治療した。其後も疼痛 子正坐不能と跛行はつづいた。3 月 3 日にレントゲン 検査で, 睡瘤如以前より増大し，判然としてきたの ですぐ手術をすることにして，6日入院左下眼内側 に約 15 徚 の皮膚切開にて直径約 3 横指位の円板状の 組織定除去した。組織学的診断は Osteoma sarcomat odes であつた。色々の都合ですすぐ切断すること にならず，4月 19 日に略半より切断した。其間 3 月 14 日，15，17，19，20日の5日間5回にわたり 1 回 150 ブつレントグン深部治療䘮行い，3月 20 日，21 日 4 月 $8,9,10,12,13,14,15,16$ 日と: 10 回ナイト ロデェンマスタードーNーオキサイド（ナイトロミン） の静注を行ひ，血液検査，副作用，組織学的変化をし らペた。

この患者任僬保として治療されているが，若し打撲 と因果関係があるとするならば，公佰として取扱就 るべきだと考へられる。我々は，交献を参考にした
り，色及調べた結果因果関係を肯定したいと思つてい る。

組織學的所見 處置前 甚しく大小不同の，一般に クロマチンに富む紡鍾形乃至円形，或任不規則な核を 有する細胞が主として束状排列を示し，或任単なる細 胞集団として何等組織棈造を示すことなく密集してい る。細胞住一般に紡錘型で胞覓構造を示さず，その間 に微細な緎維形成を認める。所々に数個の核を有する 巨態細胞も認められる。部位により多少の差はあるが かかる細胞集団内の至る所に著しい骨形成が見られ土 オジンに赤染する不規則な硝子様の仮骨から石灰沈着 に至る種々のるのが存する。以上の所見よりして骨肉 睡と診断された。

處置後 腫第細胞の排列低著しい乱れを示し, 細胞 の変性像が著しい。即ち核の変形濃縮崩壞。胞体の空 泡形成，交形，消失等が至る所火認められ且つ妈置前 の細胞の密集状態に比へ細胞は著しく粗となり，そ

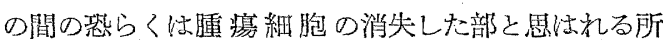
姑均一の硝子様物と化している。かかる細胞排列の乱


後に於てその亘に数ヶ所宛の標本の何れに於て子著し い盖異を認得るものであり，従つてかかる腫助組織 の変性はレントゲン線並びにナイトロゲン処置による と考へるのが妥当と考へられる(当所学研中島博士の 御好意による)。

ナイトロミンによる副作用 食䓡不振と，両下腿の 僚念感, 脚下の様な感じがあつたが，中止すると直ぐ 消失寸る。血滩像に及ぼす変化は前後差異を認めなか つた。

この患者煌白血球数讪大体 6000 位一時 4200 位にな つた。モノチーテンが約 4\%〜6\%ェオジン譛好紬胞 $4 \%$ 9\%を示していた。病的細胞出現しない棁であ る。

レントゲン像 一時一寸陰影が濃くなつた様にも認 められたが余り著しい変化结なかつた様である。

献

1 ) 生田：スポーツ外傷に続発せし肉腫 2 例及び骨の外傷性肉腫に於て 実地医学々䧗床 第10巻 昭和 8 年272頁 2) 阪本：塩田外科教堂に於今る肉腫の統計的観察 日本外科学会稚誌 第36回 昭和10年 1307 貢 3 ) 石館其他: 吉田肉腫を用いた悪性腫煌の化学潦法に関する笑験的研究（II）ナイトロデェンマスタ ードーNーオキサイド誘導体の效果 日本学士院紀要 第27巻 第9号 昭和26年１1月493貝 4) 勝沼:

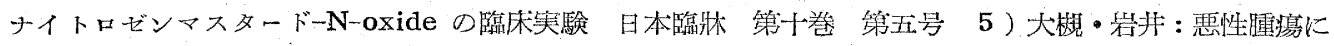
対する Nitrogen-Mustard-N-oxide の臨床的経験 第11回日本癌学会 昭和27年4月 5 日 6 ) 東京 医大内科，勝沼英守其他:ナイトロヂェンマスタードの白血病更びその類似疾患並びに癌に区济す 吉富製 薬学術課 


\title{
References
}

(1) Bancroft and Murrag:Surgical Treatment, Motor-skeletal system, 1945. (2) Symons, Nael. S:Irends in Compensation Attitude, Indust. Med. and Surg. 21;216-228, 1952 . (3) George White and Milton Elkin:Primany Malignant Bone Tumor. A Report of 93 cases observed at Pondville Hospital. 1928-1949 N. England J.M, 1951, 245:351 (4) Schwarz.H., Castanares S., and Mc Aleese G.:Palliative Therapy with Fractionated Intra-Arterial Nitrogen-Mustard:Report of its Use in a Case of Persistent Cancer of the Tongue with an unusual Complication 64:286 -291, 1952. (5) Gray, R.N., Workmen's Compensation Insurance as a Source of Data on Tumors in Relation to Occupation. A. M. A. Arch of Indust. Hyg. and Occ. M. 5:264 278, 1952, (6) Christopher:Textbook of Surgery, 1949. (7) Coley, B. L. : Mamma in Malignant Tumors of Bone. A. J. of Surgery. 73:300-304, 1947, (8) Geschickter, C. F, Copeland, M. M. Tumors of Bone, 1949. (9) Ishidate, M. etc:Proceedings of the Japan Academy. Vol. 27 : No. 9., 1951

Department of Orthopedic Surgery,Yawata Iron and Steel Works Hospital.

\section{On the Traumatic Osteogenic Sarcoma following Occupational Injury.}

\author{
by
}

\section{Tomokatsu Komatsu and Moriyoshi Nagasato}

We experienced a case of osteogenic sarcoma judged presumably secondary to the occupational injury.

The patient, a workman 21 years old, had got a severe bruise on the medialanterior aspect of the lower left femur, on Nov.1,1951,when working, and pain, swelling and dysfunction had occussed subsequently.

The pain had been so much increasing in severity that he came to receive our medical examination on Feb. 1,1952,

Examination showed the pain and the limitation of motion in the left knee joint. There was a palpable sweliing of bony-hardness adherent to the bone in the deep of the part concerned.

The roentgenogram revealed a translecent periosteal shadow above internal condyle of the femur. In the follow-up x-ray study was seen a enlarged tumor with more definite contour.

On Mar. 6, the lesion proved, on open biopsy, to be osteogenic sarcoma, histopathologically. Therefore, deep roentgen therapy was first administered in amount of 150r. each, the total being 750r. Subsequent to this therapy, "Nitromin" (Nitrogen Mustard-N-oxide) was given intravenously in $50 \mathrm{mg}$ doses every other day, with the total of $500 \mathrm{mg}$. Then, amputation was performed through the middle of the left femur. 
No appreciable reaction to the drug in blood picture, but marked loss of appetite and lassitude were complained of.

Following the administration of "Nitromin", there occurred much variation in the histopathologic appearance, compared with the biopsy Ispecimen taken before the therapy. In the majority of tumor cells, degenerations were striking, both in the nuclei and in the cytoplasms. The karyolysis and cytolysis were also common finding. The tumor cells were seen dispersed in a more disorderly fashion, and remarkably decreased in number, presenting the appearance of homogeneous hyaline substance among these cells.

Thus, Nitrogen Mustard is in efficacy and decreased in toxicity, in its $\mathrm{N}$-oxide form.

In the review of this case, being agreeable to the criteria descr ibed by Thiem or Segond after careful evaluation, the evidence for trauma as a pathogenic factor seems to be convincing.

In our opinion, Workmens' compensation may be awarded for this case. It is thought advisable to make the unbaseded provision how it is handled, based on the sound clinical and statistical evaluation. The problems presented are difficult, but we trust these thought may be of some assistance.

\section{背 椎 之土口- \\ 久留米医大整形外科教室 (主任 島 教授) 副 島 正 義

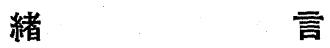

管髓腫に関する報告例は欧米諸国に於ては多数ありますが，我国に於ては割合に少く然も好登年 令は 40 才〜 60 才であつて 20 才前後の発生数は $2 \sim 3 \%$ 過ざをい様であります。吾教室に於て 最近若年者の脊椎ミエローム二例を経験しましたので弦に報告致します。

\section{症例}

\section{症 例 123 娄子小学校教員}

家族歷及び既往歷に特記すべき事まりません。

現病歷 昭昭26年1月頃より運動後, 腰痛を覚えて るたが放置して居りました所，同年 2 月21日自転事よ りとび降りた時腰部に軋音を発し急に起立不能に陌り 両下肢の知覚鈍麻至来しました。直に某病院に人院， 第三腰椎圧迫骨折の診断の下に持続牽引約 2 週ギプス 繃带約 3 ケ月, ベーレル体操約 1 ケ月間続行, 其後二 ルセツト装着して邀し委した。本年3月17日当科に
受診，主訴は腰痛及び右下腿の知覚鈍麻でまります。

現症 体格栄意中等, 顔貌壽常, 苦䦎, 憔悴の状な く嗊部其他淋巴腺腫脹及び屚桃腺肥大発赤なく一般状 態良好で多ります。腰椎而,IV部に軽度の鼠背文び左方 凸側彎が見られ可動性制限著明でもります。压痛及叮 打痛は $\mathrm{L}_{3} \mathrm{~L}_{4}$ 部に証明され特に $\mathrm{L}_{4}$ て怔雨下肢に放散 します。アヒレス腱反射は両側共正常でもりますが滕 蓋䀽反射法消失して居ります。バビンスキー徵候雨側 共強陽性でもります。就床時体位変換僅かに不自由, 